\title{
Solving the Beach Wrack Problems by On-Site Treatment with Reed Beds Towards Fertilizer Amendments
}

\author{
Alicja Kupczyk ${ }^{1 *}$, Katarzyna Kołecka' ${ }^{1}$, Magdalena Gajewska ${ }^{1}$ \\ 1 Department Water and Waste-Water Technology, Faculty of Civil And Environmental Engineering, Gdańsk \\ University of Technology, Gabriela Narutowicza 11/12, 80-233 Gdańsk, Poland \\ * Corresponding author's e-mail: alicja.kupczyk@pg.edu.pl
}

\begin{abstract}
Beach wrack is a unique issue. It is both an ecological problem for the eutrophicated reservoirs such as the Baltic Sea and the social one associated with nuisance for inhabitants and tourists visiting seaside resorts. This generates a problem for the institutions responsible for beach management (local authorities). Nowadays local authorities generally leave cleaning the beach to local companies and it is not known how the beach wrack material is utilized. According to the current trend, the nuisance of beach wrack should be turned into a resource that will bring benefits. In order to understand what beach wrack really is, it is necessary to establish a specific definition. The material washed out by the sea contains not only the natural substances of organic origin, but also human products: plastics, glass or metals, which in many cases forces to pre-select before using the technology. Good treatment of material the quantities of which are undefined and the occurrence is variable, constitutes a real challenge. The beach wrack processing on reed bed system, so far used mainly for the treatment of sewage sludge, seems to be a good idea. It is an innovative technology that is expected to have similar results as for the processing of sewage sludge from wastewater treatment, i.e. a high nutrient fertilizer. In accordance with European Union recommendations, the possible use of beach wrack as a fertilizer in agriculture or enrichment of compost, will close the circulation of organic matter in environment, thus entering the reed bed system into a circular economy. Many aspects related to the reed bed system favor the use of this technology in the practical processing of marine organic waste.
\end{abstract}

Keywords: beach wrack, eutrophication, nutrients, reed bed system, fertilizer

\section{INTRODUCTION}

Beach wrack is a very specific material, which offers many ecosystem services in the coastal zone. The microbes and other smaller organisms used by fish and plants are supported by the beach wrack occurrence. It is also a habitat for important animal communities, including shorebirds (food, nesting, and shelter). The occurrence of beach wrack also contributes to the protection of the shoreline and the coastal dunes by providing a physical barrier that dissipates the wave energy, reducing their impact force. The fibrous composition of sea grass allows to bind the drifter sand and strengthen the coastal sand dunes contributing to reducing the erosion process during winter. The decomposing organic material provides nutrients to the coastal and marine food web systems [1].
For the Baltic countries, where eutrophication is one of the most serious problems, the nutrientrich organic material thrown ashore is a real challenge, because the nutrients released from decomposing beach wrack increase this process (HELCOM, Baltic Sea Action Plan, 2007). What is more, the material accumulated on the seashore decomposes quickly, which is accompanied by a troublesome odor that keeps tourists away. Therefore, the beach wrack is not only a problematic phenomenon for the environment, where nutrients are re-released and transported to the eutrophicated reservoir, but also a factor that reduces the tourist attractiveness of the seaside resorts, thus creating a social problem. Gdańsk University of Technology is a co-partner in the CONTRA project - "Baltic beach wrack-Conversion of a nuisance to a resource and asset". The main 
assumption of the project is that the beach waste constituting a nuisance at the moment should be turned into a source that brings benefits. The project is designed to accurately describe the problem of beach wrack. One of the important tasks of the project is to clarify and understand the definition of beach wrack. The values and composition of the washed out from the Baltic Sea material will be determined, as well as various utilization variants of beach wrack will be proposed. The impact of beach wrack on society will also be examined. The aim of the project is to create a toolkit, useful for the interested sides, which will propose specific solutions of the problem.

The aim of the paper is to present all aspect of the complex problems of so-called beach wrack as well as the potential solution to solve them with accordance to the challenges of sustainable development and demands of circular economy.

\section{PROBLEMS WITH BEACH WRACK}

The definition of beach wrack makes huge problems with interpretation and solution of this troublesome phenomenon. According to Macredie [2], beach wrack is an organic material accumulating along the shores of beaches around the world. This phenomenon is natural, caused by waves, wind and tides that throw beach wrack from the sea to land. Often, the breaking waves return the same material to the system. A more inclusive definition can also be found, stating that beach wrack constitutes all the items thrown out on the wrack line, which is equivalent to the high tide line, from the open sea. They constitute not only the natural material, but also plastics, glass and metals [3]. On the basis of the currently collected data on beach wrack, it can be said that it is a mixture of marine vegetation: kelp, seaweed, seagrass, macroalgea; animal waste: stranded animal remains shells, mussels; natural land waste: terrestrial plants, wood, leaves and manmade land waste: glass, plastic, paper, rubber and textile impurities. Establishing one, coherent definition, reflecting the reality of beach wrack is a difficult challenge. The basic problem associated with the explanation of the term "beach wrack" is whether it is only organic or inorganic material and whether the wastes included in it are only of natural origin or also of anthropogenic one.

It is necessary to create legislation clearly defining this term and the provisions governing the issue of managing it. The current legal situation only says that in accordance with the European Union Directive on the bathing water quality (2006/7 /EC), the beach management authorities are responsible for the removal of macro-algae accumulating on the coast [4]. However, they cannot store them on landfills, since the discharge of biodegradable waste is prohibited in the Directive of the European Parliament and of the Council (EU) 2018/850, which refer Directive 1999/31/EC, so they must be disposed of [5].

The beach wrack is a material which high nutrient content, so it has a direct impact on the increase of the eutrophication problem occurring in the Baltic Sea. The most important issue of eutrophication is the nutrient salt content in seawater, which exerts the greatest direct and indirect impact on other eutrophication indices, including the development of phytoplankton. The phosphate (DIP-dissolved inorganic phosphorus) and inorganic nitrogen (DIN-dissolved inorganic nitrogen) content tests are carried out during the disappearance of primary production, i.e. the winter period (December, January and February according to HELCOM Eutrophication Assessment Guide), where the nutrients largely determine the intensity of primary production in the next growing season. According to the Assessment of the state of the environment of Polish sea areas of the Baltic Sea on the basis of monitoring data from 2017 against the background of the decade 2007-2016, there is a slight decrease in the content of inorganic phosphates in the surface layer of individual basins (the Bornholm Basin, the Eastern Gotland Basin and the Gdańsk Ba$\sin )$ to the average observed for winter values of the previous year. However, in all of the studied water basins, there was an upward trend both in the content of inorganic phosphorus compounds in winter and average annual concentrations. Figure 1 presents the changes in the phosphate concentrations (DIP) in Baltic sea areas.

In the case of inorganic nitrogen concentrations, in 2017 they were much higher than in the previous year, both in winter and throughout the whole year. They were also higher than the corresponding average for the years 2007-2016. The smallest overruns were recorded in the Eastern Gotland Basin. In other water basins, the average values in 2017 were almost twice as high as the average of the previous decade. In the Bornholm Basin and the Gdańsk Basin the winter accumulation of inorganic nitrogen compounds in the surface layer was also the highest in the last ten years. 

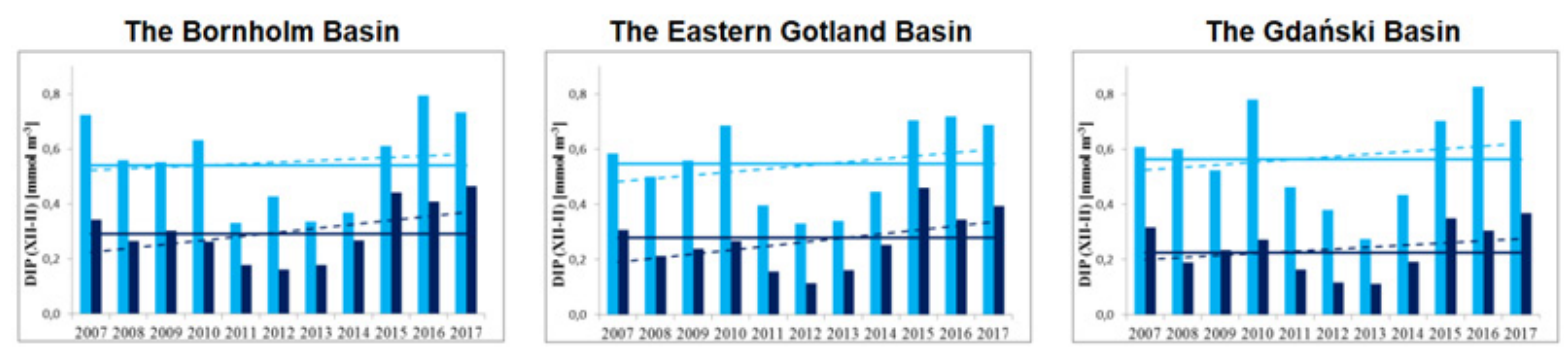

Figure 1. Changes in the phosphate concentrations (DIP) in Baltic sea areas in the winter months (XII-II) (brighter bar) and annual (darker bar) in 2007-2016 and in 2017

continuous lines - appropriate average from 2007-2016, dashed lines - trends [6]

Figure 2 presents the changes in the concentrations of inorganic nitrogen (DIN) in Baltic sea areas in the winter months (XII-II) (lighter bar) and annual (darker bar) in 2007-2016 and in 2017 continuous lines - appropriate averages from 2007-2016, dashed lines - trends [6].

During the growing season, other indicators of eutrophication are the concentrations of total phosphorus (TP) and total nitrogen (TN), which approximate the amount of primary production. The average concentration of total phosphorus from the summer months in the $0-10 \mathrm{~m}$ layer was significantly higher in 2017 than in the summer of 2016 in all studied water basins. They also stayed above the average values for the last decade. Similar dependencies concerned the average annual concentrations of total phosphorus. In all basins, there was an upward trend in total phosphorus concentrations, both for seasonal and annual averages. Figure 3 presents the changes in the TP concentrations in Baltic sea areas.

The values of the total nitrogen concentrations, both in the summer of 2017 and in the annual cycle, were higher than the long-term average, as well as in comparison with 2016, in all monitored water basins except for the Gdańsk Basin. This was confirmed by the increasing tendency of the average from the summer months and the annual concentrations of total nitrogen in these areas, which was most visible in the Gotland Basin. Figure 4 presents the changes in the $\mathrm{TN}$ concentrations in Baltic sea areas.

With reference to the indicators of the Marine Strategy Framework Directive, in 2017 none of the analyzed basins reached the good status, so in the field of eutrophication, the condition of Baltic sea areas was considered unsuitable. This condition was mainly caused by high concentrations of nitrogen and phosphorus, both total and mineral. Increased availability of nutrients in the environment resulted in intensive phytoplankton blooms, which was reflected in the increased concentration of chlorophyll-a in seawater. The primary production is also related to the transparency of water, the decrease of which is observed with the increase of the amount of algae floating in the water. The growth of nutrients limits the blooms of phytoplankton, thus indirectly also contributes to the increase in water turbidity. Both the limit values for chlorophyll-a concentration as well as seawater transparency, which have direct eutrophication effects, were exceeded. In all basins, an indirect effect of the increased nutrients dose was also observed, involving the poor oxygenation conditions of the bottom layer of the deep water zone. The above-mentioned studies show that the Baltic Sea has a problem with eutrophication, and the nutrients that are released during the decomposition of the beach wrack, which are
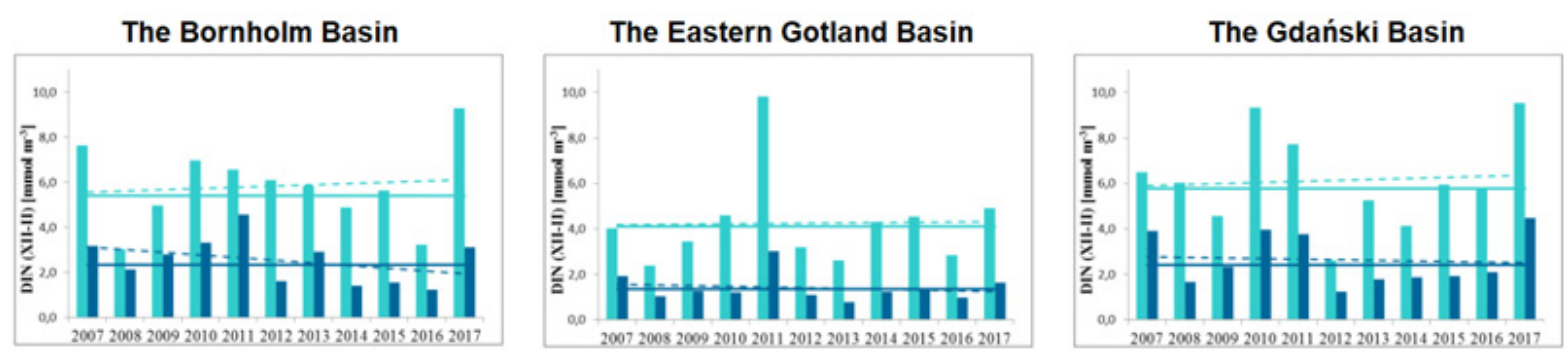

Figure 2. Changes in the concentrations of inorganic nitrogen (DIN) in Baltic sea areas. 
The Bornholm Basin

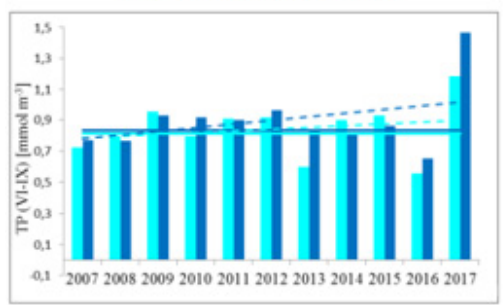

The Eastern Gotland Basin

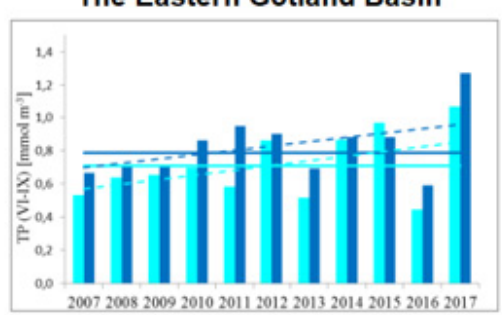

The Gdański Basin

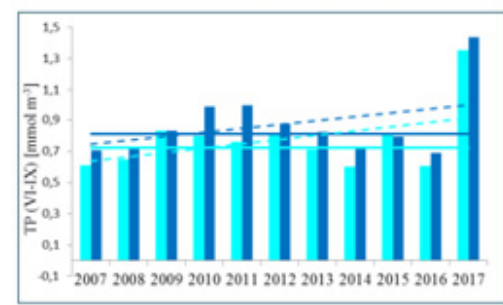

Figure 3. Changes in the total phosphorus concentrations in Baltic sea areas $(0-10 \mathrm{~m})$ in the summer months (June-September) (lighter bar) and annual (darker bars) in 2007-2016 and in

2017 continuous lines - appropriate average from 2007-2016, dashed lines - trends [6]
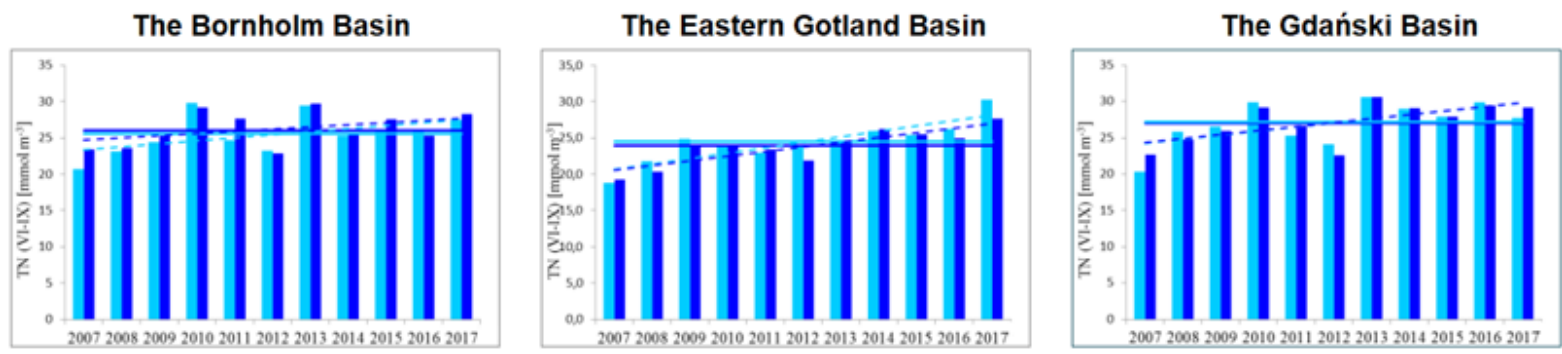

Figure 4. Changes in the total nitrogen concentrations in the summer months (June-September) (brighter bars) and annual ones (darker bars) in 2007-2016 and in 2017 continuous lines - appropriate means from 2007-2016, broken lines - trends in change [6]

recirculated back to the Baltic reservoir, certainly aggravate this problem [6].

The next problem with beach wrack involves estimating the mass of the washed out material. The beach wrack phenomenon is variable in both quantitative and qualitative terms. The occurrence of beach wrack changes seasonally. The monitoring of this phenomenon is not accurate enough on the Polish side of the Baltic sea [7]. Therefore, it is difficult to determine how significant is the problem and propose a good solution for managing this material, because the exact beach wrack weight accumulating on the Polish coasts of the Baltic Sea is not specified. The research on the Polish side of the coast was conducted mainly in Sopot, which is a seaside resort with the longest wooden pier in Europe $(512 \mathrm{~m})$ and is located in the northern part of Poland. The Maritime Institute in Gdańsk estimates the biomass of laying algae on the beach as $160-800$ tons of dry matter per year. [7] According to the Maritime Sports and Recreation Center, 180-796 tons of wet material can be collected during the season, and the Institute of Oceanology of the Polish Academy of Sciences determines the value of $220-440$ tons per season [8]. Figures 5a and 5b show accumulation and taking samples of beach wrack in Rzucewos's beach ("the seal hunter's settlement" area).
Beach wrack is specific phenomenon for the countries struggling with the eutrophication process. The lack of precise definition and no information on the amounts and quality of the washed out material on the Polish part of Baltic Sea shore, create a challenge which must be faced.

\section{Reed bed system as tool for circular economy in organic matter treatment}

One of the ideas that is worth spending more attention is utilizing beach wrack in a reed bed system. This technology has been used so far for dewatering and stabilization process for sewage sludge in wastewater treatment. Stabilization and dewatering are basic processes that occurred in the reed system and they are similar under natural conditions in a wetland ecosystem. These two processes contribute to the reduction of sewage sludge volume and mass. Figure 6 shows the process of dewatering and stabilization in a reed system.

Dewatering, which occurs most quickly during the delivery of the raw material is caused by evapotranspiration of water from the aboveground parts of the plant, as well as percolation of water through the bed and drainage as reject water, which contributes to increasing the dry matter content. Natural factors such as temperature, photodegradation or solar radiation support 
a)

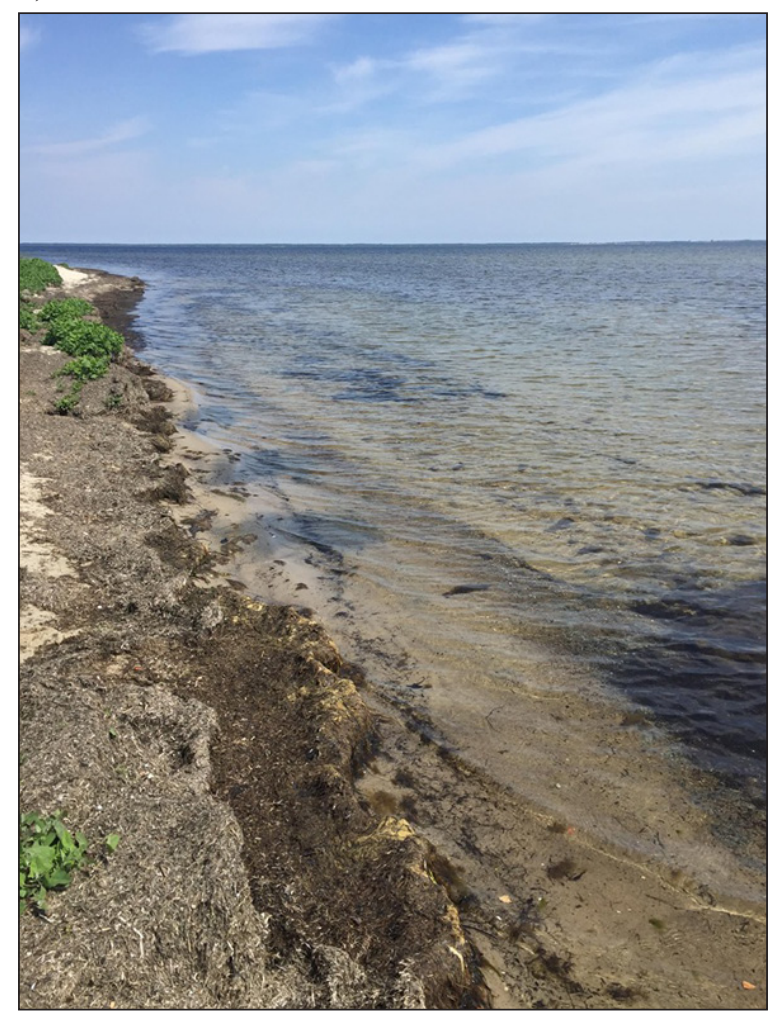

b)

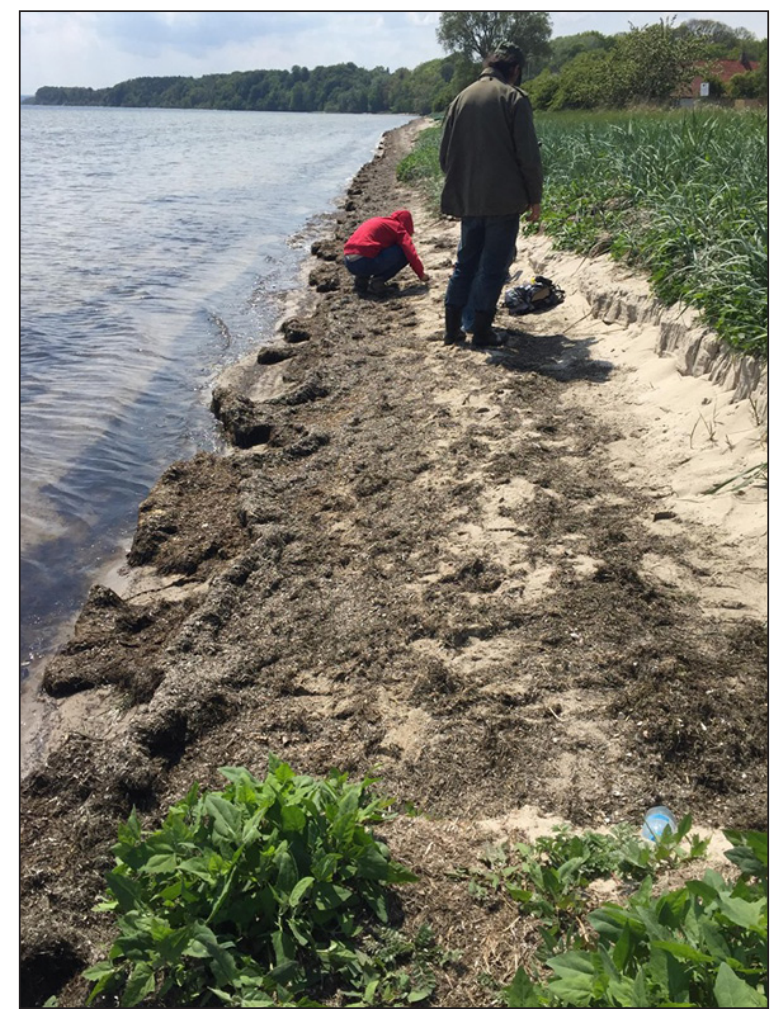

Figure 5a. Beach wrack accumulating on beach in Rzucewo (photo A. Kupczyk)

Figure 5b. Taking samples of beach wrack (photo A. Kupczyk)

these processes. In the reed bed system, the process of stabilization leads to the mineralization of organic matter. The aim is not only the reduction of volume and mass but also the reduction of rot as well elimination of sewage sludge odors. The stabilization takes place both under aerobic and anaerobic conditions. Reed shoots transport oxygen from the atmosphere to the roots of the plant, and from there to the surrounding soil. This process causes the formation of local aerobic microspheres (from $\mathrm{O}_{2}$ ), around which there are hypoxic microspheres (without $\mathrm{O}_{2}$ in the presence of $\mathrm{NO}_{3}^{-}$), followed by reductive microspheres (without $\mathrm{O}_{2}$ and $\mathrm{NO}_{3}^{-}$). These conditions favor the development of heterotrophic microorganisms that are involved in the biochemical changes of the incoming pollutants. Different values of oxidation-reduction potentials occurring in the forming microspheres cause the decomposition of organic matter as well as the transformation of nitrogen

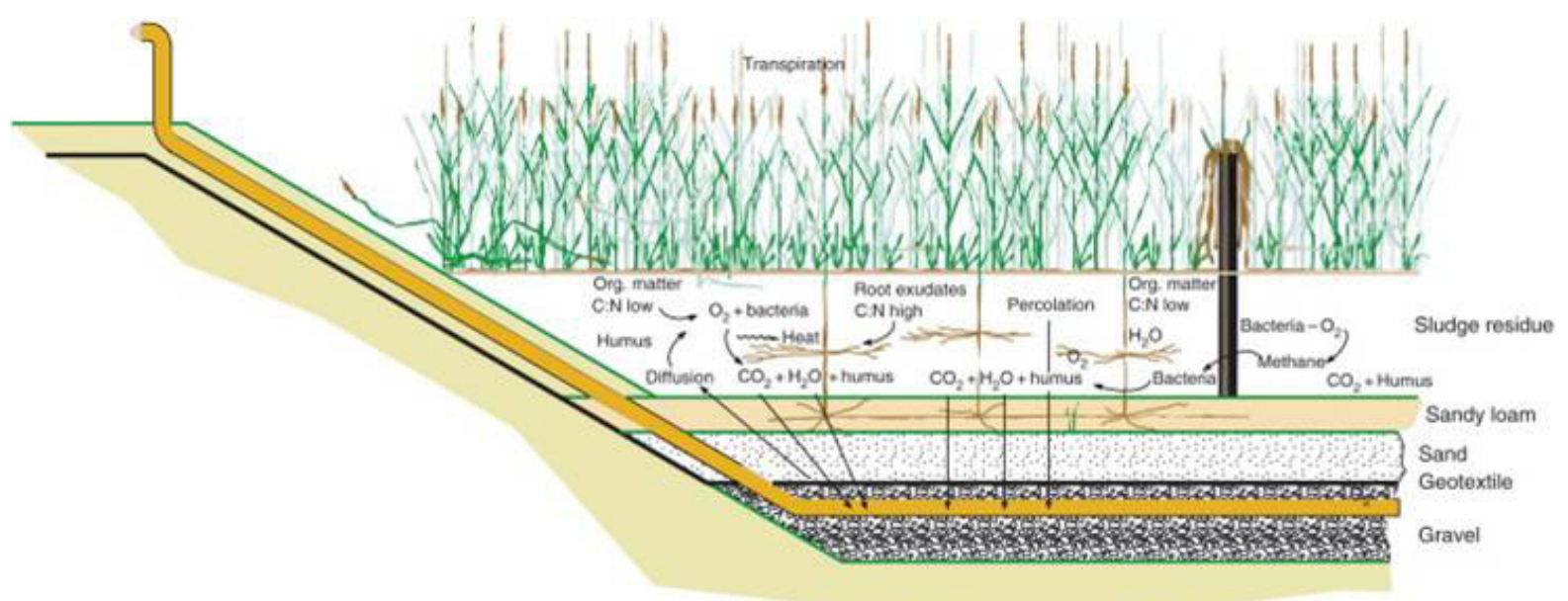

Figure 6. Processes (dewatering and stabilization) in reed system for sewage sludge [9] 
compounds. The oxidation of harmful products of anaerobic reactions and aerobic stabilization of sewage sludge takes place in aerobic zones. [10] Figure 7 presents the changes in the sewage sludge volume after treatment on reed bed system.

The raw sludge usually contains about $99 \%$ water. After treatment on both short-term and long-term reed beds, significant dewatering of the sewage sludge can be observed. In the case of a 3-year sludge treatment, a reduction in the volume about $87 \%$ in the top layer and $92 \%$ in the bottom layer can be observed. In the case of a 12 -year treatment, the volume decrease is $93 \%$ in the top layer of the deposit and $96 \%$ in the bottom layer, respectively. Table 1 presents the comparison of basic parameters in raw sewage sludge and sewage sludge after reed bed system.

The dewatering efficiency is affected by the retention time of sludge in the reed bed system, what is more, the dry matter content increases with the depth of deposited sludge. Dewatering of sewage sludge in reed beds is equally efficient and much cheaper than the conventional mechanical methods, which additionally consume a large amount of energy and need chemicals to improve the efficiency of the process [12].

The stabilization process contributes to reducing the intensity of unpleasant odors and the amount of pathogenic organisms, it also supports the dewatering process.

The simplicity of technical solutions makes reed bed system easy to understand for a layman, which definitely supports the use of such a solution [13].

The reed bed system works in an altering cycle. The working cycle of the beds consist of the irrigation phase - the supply of raw material and the resting phase. During rest periods followed by dewatering and stabilization as a result of intense processes in the deposit [12].

In the conversion of current economic activity of a liner-like nature to activities that meet the assumptions of the European Commission's package of 2 December 2015 on the implementation of the circular economy, great sign in use of reed bed system. The recovery of nutrient compounds from sewage sludge through the use of this technology takes place without the need of previous dewatering or compaction - no additional energy consumption. The method uses energy only for the pumps feeding sewage sludge to the system, which contributes to low energy consumption. No additional chemicals to improve the processes occurring in the reed bed are necessary - no additional environmental load of anthropogenic substances is introduced. The heavy equipment is only used in this method to empty beds (every 10-15 years) [14].

The method using reed beds is cheap at the stage of construction as well as during exploitation time [13]. This system also gives the possibility to produce fertilizer (after meeting the requirements of the Act of 10 July 2007 on fertilizers and fertilization), which may be an additional source of income for the company which will be using this method. Low investment costs as well as operational costs and additional income from the sale of fertilizer constitute a significant asset for the potential system users.

Natural look of reed beds, which is easy to fit in the surrounding landscape, is another advantage of this method [15].

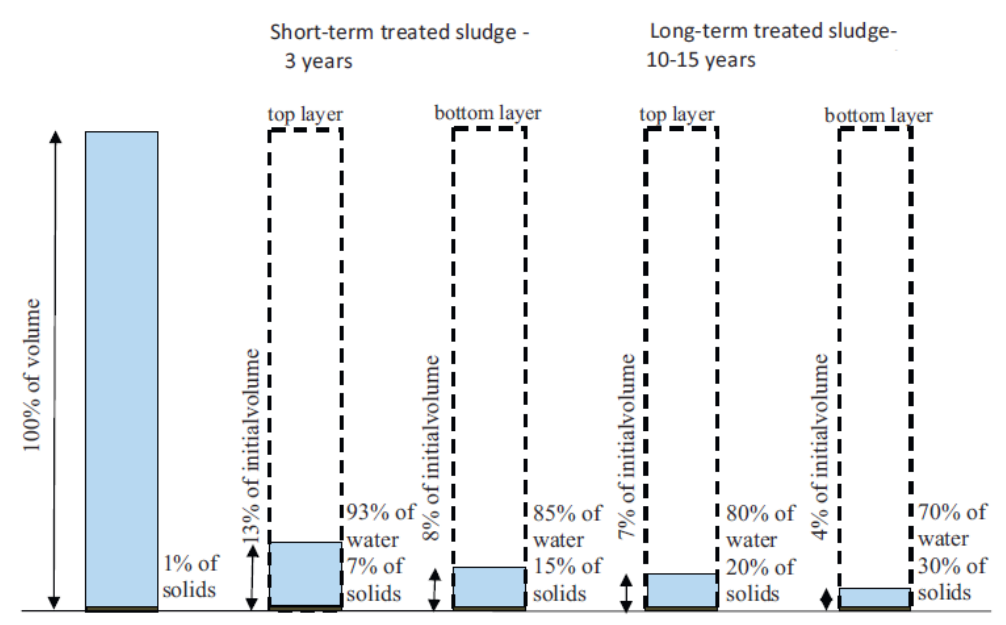

Figure 7. Changes in the solids and water content in volume of sewage sludge after treatment on reed bed system. [11] 
Table 1. Changes in basic parameters of raw sewage sludge after treatment on reed bed systems (RBS), based on [12]

\begin{tabular}{|l|c|c|}
\hline \multicolumn{1}{|c|}{ Parameter } & $\begin{array}{c}\text { Raw sewage } \\
\text { sludge }\end{array}$ & $\begin{array}{c}\text { Sewage sludge } \\
\text { after RBS }\end{array}$ \\
\hline Dry matter & $0.6-7$ & $18-42$ \\
\hline $\begin{array}{l}\text { Organic matter \% } \\
\text { d.m. }\end{array}$ & $58-74$ & $41-60$ \\
\hline Total Nitrogen & & $2.4-3.6$ \\
\hline Total Phosphorus & & $0.1-4.1$ \\
\hline
\end{tabular}

The reed systems are an environmentally friendly solution. The method is low-emission and also provides a solution with low energy consumption compared to the conventional methods of treatment sewage sludge. The processes taking place in the system are based on the naturally occurring mechanisms in the environment, occurring in both aerobic and anaerobic zones. As a result of oxygen processes, carbon dioxide is formed as a byproduct, in addition, methane is formed in the anaerobic processes. Despite the emission of greenhouse gases, which is inevitable, due to the mineralization process, wetland systems are still an environmental friendly technology. If a system is well functioning, the presence of reeds reduces the amount of methane produced to a minimum, and also supports oxidation of methane by aerobic methanotrophic bacteria [12].

This method does not require the use of additional substances that improve the efficiency of processes, such as, for example, polyelectrolytes. The reed bed system does not introduce additional substances in the form of chemicals into the environment, which favors the ecological trend. Moreover the lack necessity of using additional substances also affects the reduction of operating costs, because all reactions take place without the additional interference of often expensive chemicals [16].

The downside and potential threat to the use of a reed bed system may be the fact that they require a significant area. Moreover, the time needed to start up the object can be a downside of this technology. The construction of the system is simple but requires a proper design and precision of workmanship, their lack may be the reason for the incorrect operation of the system [12].

\section{Application of RBS for beach wrack}

Observations and current beach wrack management methods provide operational knowledge about them. Cleaning the beach is the responsibility of the relevant local institutes. Typically, this is done by mechanically collecting the material containing natural and manmade waste, thrown out by the sea into the shoreline. This is a very important issue in the case of indicating the appropriate directions of beach wrack management so that their use will be a part of circular economy. The methods aimed at converting the beach wrack from the nuisance to the resource depend mainly on their composition. Different technologies are designed for different groups of substrates. Some of them may use only the natural part of beach wrack, while others may use all the material accumulating on the coast together with waste of manmade origin.

Beach wrack processing in a reed system is an innovative solution that will be investigated in the CONTRA project by the Gdańsk University of Technology. Beach wrack will be colleced by hand from the beach area in Rzucewo (village located on the Puck Bay) and transported to the pilot plant of reed system which will be built in the wastewater treatment in Swarzewo (about $12 \mathrm{~km}$ from Rzucewo). Beach wrack will be collected on an unmanaged area of the beach, where there is apparently a significant accumulation of beach wrack material. Before feeding the material of beach wrack to a reed bed system, pre-selection of the material will be carried out. The waste of human origin such as cans, plastic bottles, nets, etc, will be separated from organic part of substrates.

The pilot reed bed system will be made using cubes, placed on wooden pallets. The dimensions of the cubes should be $1 \times 1 \times 1 \mathrm{~m} \pm 20 \%$. The top of each container will be felled. Each cube will be divided into four parts, using walls made of plexiglass. The division will be made in order to save the space allocated to the object as well as the possibility of providing a smaller amount of material for testing. A different form of material will be fed into each of the $1 / 4$ parts of the cube (e.g. first part - unprocessed algae, second part - shredded algae, third part - ground algae with compost in a given weight ratio, etc.). It is planned to make 2 cubes, which will provide 8 independent quarters. The filling of the bed will constitute three layers of filtration material: growth layer: located in the upper part of the quarters - sand with a grain size of $0.32-2.5 \mathrm{~mm}$, thickness $15 \mathrm{~cm} \pm 20 \%$; intermediate layer: made of gravel with a grain size of 2.5-10 mm, thickness $20 \mathrm{~cm} \pm 20 \%$; drainage layer (the deepest): made of crushed stone with a 
grain size of $10-40 \mathrm{~mm}$, thickness $25 \mathrm{~cm} \pm 20 \%$. A free space will be left over the filling, where the material used for the research will be fed. In the growth layer will be planted reed cuttings (Phragmites australis). At least 2 reed cuttings should be planted in each part of the cubic quarter. In the drainage layer, drainage will be made, collecting the reject water as well as ensuring aeration and ventilation of the system, for every quarter of the cube. Drainage $=80 \mathrm{~mm}$ will be run in such a way that it collects separately the reject water from each part. Next, they will be collected into a portable container (eg. a canister 201 by means of a flexible tube connected tightly to the drainage). Above the designed height of the drainage system, ventilation chimneys will be installed, ensuring a constant air supply. Figure 8 shows cube model of pilot plant reed system.

Monthly sampling of dewatered and stabilized material from reed bed and reject water is planned. As it was written above, two pilot objects are to be created. One of them will be fed the same beach wrack in various forms, and in the second beach wrack will be mixed with a compost in a different ratio to improve the fertilizing properties.

After using the beach wrack in the reed bed system, similar effect as in the case of processing sewage sludge is expected. It can be concluded that in the case of using macroalgae the results of increase of dry matter content, through dewatering and reduction in volume will be similar. As a result of using beach wrack on the reed bed system, high nutrient fertilizer is expected to be achieved. In the case when material from the reed bed system will not complied with the requirements for fertilizers, work on it will not be a waste of time, because the biologically stabilized material can be stored on the landlifts.

Table 2 presents the current knowledge about the use of sewage sludge in the reed bed systems and the issues that must be verified during using beach wrack in this type of object.

Beach wrack processing in a reed system seems to be a good solution for utilizing beach wrack. As it can be seen from the above-mentioned concept of a pilot plant, the reed bed systems are characterized by a simple construction, which increases the attractiveness of such solution.

Seasonality, as well as quantitative variability of the occurrence of beach waste is a problem for many other technologies, e.g. the use of the organic part of the material as a raw material in biogas plants, due to the lack of a constant supply of substrate. In the case of reed bed systems, this problem does not exist because they operate in an alternating cycle.

In addition, the use of beach wrack on reed bed system is connected with circular economy. This technology minimizes the impact on the environment, due to minimal emissivity, low energy consumption as well as the change of the previous nuisance - beach wrack, on the resource. Beach wrack processing with this method gives the opportunity to use this material for the production of possible high-nutrient fertilizer, which used for agriculture or for the reclamation of degraded areas will release nutrients again into the circulation

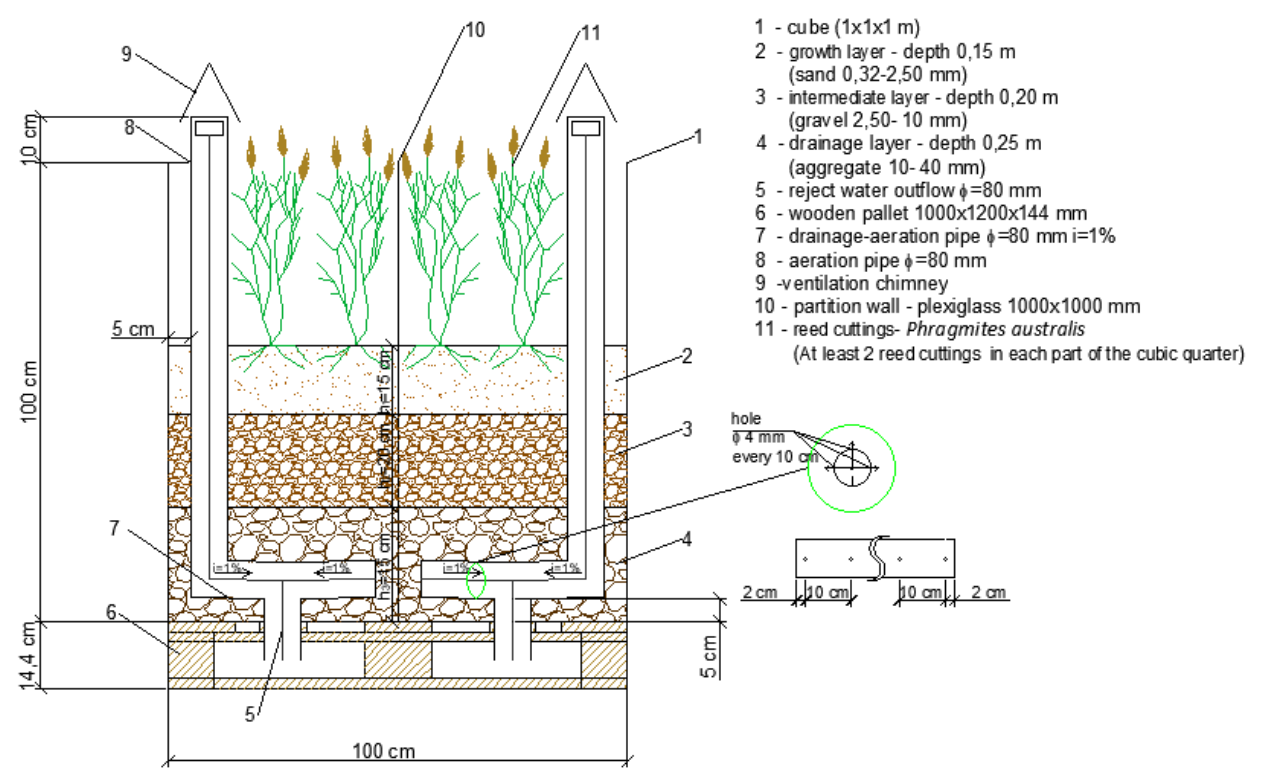

Figure 8. Pilot plant reed system 
Table 2. Current knowledge about the use of sewage sludge in the reed bed systems and the issues that must be verified during using beach wrack in this type of object

\begin{tabular}{|c|c|c|}
\hline Parameters & Reed bed syetem for sewage sludge & Reed bed system for beach wrack \\
\hline Method of material feeding & $\begin{array}{l}\text { supply with vertical pipes terminated } \\
\text { with a „mushroom” or with a system of } \\
\text { pipes along one side or corner (evenly } \\
\text { distribution of sewage sludge on the } \\
\text { entire surface) [12] }\end{array}$ & $\begin{array}{l}\text { planned manual feeding and evenly } \\
\text { distribution of material on the bed }\end{array}$ \\
\hline The form of the material fed into the bed & $\begin{array}{l}\text { sewage sludge directly from a given } \\
\text { stage of wastewater treatment (without } \\
\text { prior processing) }\end{array}$ & $\begin{array}{l}\text { beach wrack collected from the beach, } \\
\text { after the selection of human origin } \\
\text { wastes, fed into the bed: as raw form } \\
\text { (macroalgae), shredded algae and } \\
\text { addition to compost in a different ratios, } \\
\text { in aim to selection best form for treatment } \\
\text { in the reed bed system }\end{array}$ \\
\hline $\begin{array}{l}\text { System performance: - start-up } \\
\text { period - full exploitation period }\end{array}$ & $\begin{array}{l}>30 \mathrm{~kg} / \mathrm{m}^{2 *} \text { rok } \\
50-60 \mathrm{~kg} / \mathrm{m}^{2 *} \text { rok [12] }\end{array}$ & $\begin{array}{l}\text { it is necessary to establish appropriate } \\
\text { dose }\end{array}$ \\
\hline $\begin{array}{l}\text { Quality of dewatered and stabilized } \\
\text { material in reed system }\end{array}$ & $\begin{array}{l}\text { significant increase in dry matter } \\
\text { content and volume reduction, lower } \\
\text { concentration of organic matter, high } \\
\text { concentration of nutriens and low } \\
\text { concentration of heavy metals enabling } \\
\text { the use of fertelizer in agriculture and } \\
\text { reclamation [12] }\end{array}$ & $\begin{array}{l}\text { expected similar results as when } \\
\text { using sewage sludge, meeting the } \\
\text { requirements concerning fertilizers }\end{array}$ \\
\hline $\begin{array}{l}\text { Quality of reject water drainaged from } \\
\text { reed systems }\end{array}$ & $\begin{array}{l}\text { good quality reject water in a small } \\
\text { amount that enable recycling at the } \\
\text { beginning of the wastewater treatment } \\
\text { process without negatively affecting the } \\
\text { work of the wastewater treatment [12] }\end{array}$ & $\begin{array}{l}\text { the quality and quantity of reject water is } \\
\text { unknown, it will be determined }\end{array}$ \\
\hline
\end{tabular}

of matter in nature, in the places where it is desirable, while reducing the impact on deepening the eutrophication process of the Baltic Sea.

The financial issues are an important matter for the institutions responsible for managing beach wrack. The use of beach wrack in reed systems, like sewage sludge, seems to be economically viable. The costs of construction and operation of the system are low, and an additional advantage of this method in relation to organic marine waste is the expected production of fertilizer, which will be an additional source of income for the investor.

The cost-effectiveness of the reed method in the case of beach wrack is also associated with the transport distances. Systems can be built in a short distance from the beach (place where will be collecting of beach wrack), which contributes to their economic profitability. Beach wrack is a material with a high water content, which contributes to its large mass and volume that must be transported to the place of processing. Transport of material over large distances can increase operating costs and make the business unprofitable in the final summary. Reed systems are a nice solution for the eye, which can complement the existing seaside landscape. Furthermore, reed beds are an alternative to the reconstruction and builing of dunes.

\section{CONCLUSIONS}

In summary, marine waste is a specific material with a composition that is difficult to determine. Their occurrence and composition variability affect the increase in the difficulty of their management. The lack of a legally defined definition and specific methods of dealing with this waste makes the treatment of beach wrack challenging. It is necessary to monitor the beach wrack on the beaches of eutrophicated water reservoirs, because they cause the return of nutrients to the highly trophic, problematic reservoirs like the Baltic Sea. The search for appropriate beach wrack management methods has just begun. The goal is to use marine wastes in such a way that they stop being an environmental and social nuisance, and become a valuable resource which can bring benefits. Reed systems that work well in the case of processing of sewage sludge from various technological stages of wastewater treatment, constitute an interesting solution fitting to the circular economy. Beach wrack, similarly to sewage sludge, has a high content of water and organic substances, which is why their innovative processing in wetlands systems may turn out to be great success. 


\section{Acknowledgments}

The authors would like to thank the European Regional Development Fund (ERDF) in the Interreg Baltic Sea Region program, the main institution financing the CONTRA project "Baltic Beach Wrack - Conversion of Nuisance To a Resource and Asset" (Project Number: \# R090). Acknowledgments are also directed to the Gdańsk University of Technology for the management staff of the institution for consent to conduct research and their assistance during the research. The authors are grateful to the Wastewater Treatment Plant in Swarzewo for providing space for the construction for pilot plant of reed bed system.

\section{REFERENCES}

1. Government of south Australia, Coast Protection Board (2017). What is beach wrack?

2. Coastline Factsheet, 38.

3. Macreadie, P.I., Trevathan-Tackett, S.M., Baldock, J.A. and Kelleway, J.J. (2017). Converting beachcast seagrass wrack into biochar: A climate-friendly solution to a coastal problem. Science of the Total Environment, 574: 90-94.

4. Wrack, http://www.beachapedia.org/Wrack

5. Directive 2006/7/EC of the European Parliament and of the Council of 15 February 2006 concerning the management of bathing water quality and repealing Directive 76/160/EEC .

6. Directive (EU) $2018 / 850$ of the European Parliament and of the Council of 30 May 2018 amending Directive 1999/31/EC on the landfill of waste .

7. Ocena stanu środowiskapolskich obszarów morskich bałtyku na podstawiedanych monitoringowych z roku 2017 na tle dziesięciolecia 2007-2016 (The assessment of the state of the environment of Polish sea areas of the Baltic Sea on the basis of monitoring data from 2017 against the background of the decade 2007-2016), (2018), edited by: Krzymiński W., published by: Inspekcja Ochrony Środowiska.
8. Kompendium Submariner: Ocena Innowacyjnych i Zrównoważonych Sposobów Wykorzystania Zasobów Morza Bałtyckiego (Compendium Submariner: Evaluation of Innovative and Sustainable Ways of Using the Baltic Sea Resources). (2013) edited by: Schultz-Zehden A., Matczak M., published by: Instytut Morski w Gdańsku, ISBN 978-83-62438-14-3.

9. Wetlands Algae Biogas - A Southern Baltic Sea Eutrophication Counteract Project. (2012) edited by: Hansson A., Tjernström E., Gradin M., Finnis P., published by: Municipality of Trelleborg Editors, ISBN 978-91-87407-00-0.

10. Nielsen S., Cooper D. J. (2011). Dewatering sludge originating in water treatment worksin reed bed systems, Water Science \& Technology, 64.2: 362.

11. Kołecka K., Rohde D., (2018). Systemy trzcinowe jako metoda odwadniania i stabilizacji osadów ściekowych dla małych i średnich oczyszczalni, Rynek Instalacyjny, 3: 102-105.

12. Kołecka K., Gajewska M., Obarska-Pempkowiak H., Rohde D., (2016) Integrated dewatering and stabilization system as an environmentally friendly technology in sewage sludge management in Poland, Ecological Engineering, 98: 346-353.

13. Kołecka K., (2019) Usuwanie zanieczyszczeń I stabilizacja osadów ściekowych w systemach trzcinowych., vol. 149, Wydawnictwo Polskiej Akademii Nauk, Warszawa.

14. Kołecka K., Rohde D., (2018). Zalety i problemy związane z zagospodarowaniem osadów ściekowych metodą trzcinową. Rynek Instalacyjny, 5: 20-25.

15. Kołecka K., Obarska-Pempkowiak H., Gajewska M., (2018). Oczyszczalnie hydrofitowe jako wdrożenie założeń idei gospodarki o obiegu zamkniętym, Rocznik Ochrona Środowiska, 20, 1350-1371.

16. Sobczyk R., Sypuła M., (2011). Wykorzystanie makrofitów do przetwarzania osadów ściekowych na mursz, Forum Instalatora, 4: 46-48 .

17. Obarska-Pempkowiak H., Kołecka K., Buchholtz K., Gajewska M., (2015). Ekoinżynieria w zintegrowanym odwadnianiu i stabilizacji osadów ściekowych w systemach trzcinowych, Przemysł Chemiczny, vol. 94, 12: 2299-2303. 